\title{
PELATIHAN MANAJEMEN USAHA DAN PEMBUATAN MERK
}

\author{
Aprih Santoso 1), Witjaksono E.H ${ }^{2)}$, Emaya Kurniawati ${ }^{3)}$ \\ Fakultas Ekonomi Universitas Semarang 1,2,3) \\ J1. Soekarno Hatta Tlogosari, Semarang 50196 \\ Email: aprihsantoso@ usm.ac.id ${ }^{1)}$
}

\begin{abstract}
ABSTRAK
Tujuan PKM ini adalah memberikan pelatihan tentang manajemen usaha dan penyuluhan tentang pentingnya suatu merk bagi hasil produksi sehingga produknya lebih dikenal pasaran secara lebih luas. Adapun permasalahan utama mitra adalah ketidaktahuan mengenai bagaimana melakukan usaha dengan baik mulai dari perencanaan, pelaksanaan sampai dengan pemasarannya dan juga kurang mengetahui arti pentingnya sebuah merk untuk suatu produk. Solusi yang ditawarkan adalah pemberian pelatihan mengenai manajemn usaha, mekanisme legalitas izin usaha. Luaran kegiatan yang ingin dicapai agar mitra dapat mengembangkan usaha disertai kelengkapan legalitas pendirian yang memadai, sehingga operasional usaha dapat berlangsung sesuai ketentuan yang ada, Hasil pelatihan dapat menunjang kesuksesan usaha dari pelaku usaha di Kelurahan Genuksari dan telah terlaksana dengan sukses. Hal ini terbukti dengan antusiasnya peserta pelatihan mengikuti dan berdiskusi (termasuk proses tanya jawab) dengan rutin.
\end{abstract}

Kata kunci: manajemen, merk, legalitas

\begin{abstract}
The purpose of this PKM is to provide training on business management and counseling on the importance of a brand for the production so that the product is more widely known to the market. The main problem of partners is ignorance about how to do a good business starting from planning, implementation to marketing and also not knowing the importance of a brand for a product. The solution offered is the provision of training on business management, the legality mechanism of business licenses. The output of the activity to be achieved so that partners can develop the business accompanied by adequate legality of establishment, so that business operations can take place according to existing provisions, the results of the training can support the business success of business actors in the Genuksari Village and have been successfully implemented. This was proven by the enthusiasm of the trainees to follow and discuss (including the question and answer process) routinely.
\end{abstract}

Keywords: management, brand, legality 


\section{PENDAHULUAN}

Dengan berlokasi di Aula Kantor Kelurahan Genuksari Kecamatan Genuk Kota Semarang dengan alamat di Jl. Genuksari No 1 Genuk Semarang inilah Tim PKM melakukan kegiatan pengabdian kepada masyarakatnya. Di kelurahan ini terdapat RW sebanyak $11 \mathrm{RW}$, yangmana dari sejumlah RW yang ada, terdapat penduduknya yang memiliki potensi usaha dibidang produksi telur asin. Pelaku usaha UMKM produksi telur asin disini ternyata masih banyak yang tidak paham akan manajemen usaha akibatnya usahanya yang dijalankan masih belum tertata mulai dari berproduksi, keuangan atau pembukuan sampai pada pemasarannya. Pelaku usaha UMKM menghasilkan produksi berupa telur asin ini ternyata telur asin ya masih tanpa merk alias belum dimilikinya suatu merk tertentu pada telur asinnya, yangmana sebenarnya jika dilihat dari hasil produksi telur asinnya sendiri, produk telur asinya memiliki kelebihan yang tidak kalah enak dibanding dengan telur asin lain yang dijual di pasaran, akibat tanpa merk inilah maka masyarakat umum belum banyak ynag mengenal telur asin hasil produksi pelaku usaha UMKM warga Kecamatan Genuk Semarang tersebut. Selain itu, merk juga sebagai tanda pembeda dan merk juga memiliki fungsi penting sebagai hak kepemilikan pelaku usaha UMKM agar merk yang mereka miliki terhindar dari penjiplakan/peniruan oleh pelaku usaha UMKM telur asin lain. Fungsi inilah yang oleh pelaku usaha UMKM belum ketahui sebagai legatitas merk, karena berdasarkan pemahaman pelaku usaha UMKM tersebut, selama ini merk hanya sekedar tanda pembeda saja. Berdasarkan hasil survei diketahui bahwa permasalahan calon mitra PKM ini yang dalam hal ini adalah pelaku usaha UMKM produksi telur asin di Keluraahan Genuksari Kecamatan Genuk ini ternyata mereka belum tahu tentang cara yang harus dijalankannya untuk suatu usaha agar usahanya bisa lebih baik sehingga akhirnya usahanya dapat dipertahankan dan dikembangkan kemajuannya.

Fokus pengabdian kepada masyarakat ini dilaksanakan untuk pelaku usaha telur asin sebagai target program di Kelurahan Genuksari Kecamatan Genuk Semarang. Adapun tujuan PKM ini agar supaya terjadi pemahaman terkait legalitas (merk) dan manajemen usaha pada pelaku usaha UMKM telur asin, yang meliputi: pembuatan merk, manajemen produksi, manajemen keuangan, dan manajemen pemasaran sehingga pelaku usaha UMKM telur asin tersebut nantinya dapat menerapkan dalam kegiatan usaha serta kualitas usaha yang sedang dijalankan dapat diperbaikinya. Dalam pelaksanaan PKM ini disamping diberikan pelatihan tentang manajemen usahajuga dilakukan penyuluhan tentang pentingnya suatu merk bagi hasil produksi. Hal ini dengan harapan masayarakat umum dapat lebih mengenal produk pelaku usaha UMKM.

\section{TINJAUAN PUSTAKA}

\subsection{Ruang Lingkup UMKM (Usaha Mikro, Kecil, dan Menengah)}

Undang-undang nomor 20 tahun 2008 tentang Usaha Mikro, Kecil, dan Menengah telah mendefinisikan UMKM sebagai:

1) Usaha mikro adalah usaha produktif milik orang perorangan dan/atau badan usaha perorangan yang memenuhi kriteria Usaha Mikro sebagaimana diatur dalam Undang-Undang ini. 
2) Usaha Kecil adalah usaha ekonomi produktif yang berdiri sendiri, yang dilakukan oleh orang perorangan atau badan usaha yang bukan merupakan anak perusahaan atau bukan cabang perusahaan yang dimiliki, dikuasai, atau menjadi bagian baik langsung maupun tidak langsung dari Usaha Menengah atau Usaha Besar yang memenuhi kriteria Usaha Kecil sebagaimana dimaksud dalam Undang-Undang ini.

3) Usaha Menengah adalah usaha ekonomi produktif yang berdiri sendiri, yang dilakukan oleh orang perorangan atau badan usaha yang bukan merupakan anak perusahaan atau cabang perusahaan yang dimiliki, dikuasai, ataupun menjadi bagian baik langsung maupun tidak langsung dengan Usaha Kecil atau Usaha Besar dengan jumlah kekayaan bersih atau hasil penjualan tahunan sebagaimana diatur dalam Undang- Undang ini.

Kekayaan dan hasil penjualan, menurut Undang-Undang Nomor 20 tahun 2008 pasal 6, menyatakan bahwa:

a) Kriteria usaha mikro, ialah: (1) Kekayaan bersih yang dimiliki terbanyak Rp 50.000.000,00, belum termasuk bangunan dan tanah tempat usaha; atau (2) Hasil penjualan tahunan yang dimiliki terbanyak Rp 300.000.000,00.

b) Kriteria usaha kecil, ialah: (1) Kekayaan bersih yang dimiliki Rp 50.000.000,00 - Rp 500.000.000,00 belum termasuk bangunan dan bangunan tempat usaha; atau (2) Hasil penjualan tahunan yang imiliki Rp 300.000.000,00 - Rp 2.500.000.000,00.

c) Kriteria usaha menengah, ialah: (1) Kekayaan bersih yang dimiliki Rp 500.000.000,00 - Rp 10.000.000.000,00; atau (2) Memiliki hasil penjualan tahunan yang dimiliki Rp 2.500.000.000,00 - Rp 50.000.000.000,00.

Terdapat 4 (empat) posisi strategis UMKM di Indonesia, yaitu: (1) Tiidak diperlukannya modal besar untuk membentuk UMKM. (2) UMKM tidak menuntut adanya tenaga kerja yang berpendidikan formal tertentu. (3) UMKM menempati area di pedesaan serta belum butuh infrastruktur yang banyak. Dan (4) Dimilikinya ketahanan yang kuat oleh UMKM saat krisis ekonomi terjadi.

Peranan penting yang dimiliki UMKM dalam perekonomian, khususnya dalam hal berkontribusinya pada PDB (Produk Domestik Bruto). Oleh karena itu, pemerintah dan pihak swasta lainnya selalu memberi perhatian besar demi perkembangan UMKM. Peran yang dimiliki UMKM adalah dalam mendistribusikan hasil-hasil pembangunan. UMKM akan bermanfaat bila sumber dayanya (tenaga kerja) tersrap dan dicapainya pertumbuhan ekonomi yang maju. Peran UMKM dapat terciptanya kesempatan kerja dan sumber pertumbuhan PDB (Produk Domestik Bruto). Kontribusi besar terhadap pertumbuhan ekonomi Indonesia khususnya di sektor industri, perdagangan dan transportasi juga telah diberikan oleh UMKM-UMKM.

Diberikannya manfaat sosial atas peran UMKM berupa ketimpangan pendapatan yang tereduksi. Peranan UMKM bukan saja penyediaan barang-barang dan jasa yang berdaya beli rendah, namun juga bagi konsumen perkotaan yang memiliki berdaya beli tinggi atas produk-produk UMKM tersebut. Disamping itu, UMKM dapat menyiapkan bahan baku atau jasa untuk perusahaaan besar. Dicapainya tingkat kesejahteraan 
minimum, yaitu menjamin kebutuhan dasar rakyatlah yang menjadi tujuan sosial keberadaan UMKM ini.

\subsection{Manajemen Usaha}

G.R. Terry dalam Hasibuan (2009) menyatakan manajemen merupakan proses atas tindakan-tindakan perencanaan, pengorganisasian, penggerakan dan pengendalian untuk mencapai sasaran-sasaran yang telah ditetapkan melalui pemanfaatan sumber daya manusia dan sumber-sumber lainnya. Definisi ini memfokuskan tekanan terhadap kenyataan bahwa manajer mencapai tujuan atau sasaran dengan mengatur karyawan dan mengalokasikan sumber-sumber material dan keuangan. Bagaimana manajer mengoptimasi pemanfaatan sumber-sumber, memadukan menjadi satu dan mengkonversi hingga menjadi output? Manajerlah yang harus melaksanakan fungsi-fungsi manajemen untuk mengoptimalkan pemanfaatan sumber-sumber dan koordinasi pelaksanaan tugastugas untuk mencapai tujuan tersebut.

Choliq (2011) menyatakan bahwa fungsi manajemen ialah: perencanaan (planning), pengorganisasian (organizing), kepemimpinan (leading), dan pengendalian (controlling). Berlandaskan pada fungsi dasar manajemen teraebut, maka melakukan tindak lanjut setelah mengetahui bahwa yang telah mereka tetapkan apakah belum tercapai ataukah justru sudah tercapai. Menurut Amirullah (2015) justru ada lima fungsi manajemen, ialah: Planning, Organizing, Commanding, Coordinating, Controlling, Berdasarkan fungsi manajemen itulah yang harus dilakukan manajer dengan berturut-turut agar proses manajemennya bisa diimplementasikan dengan bagus termasuk di dalam memanajemen suatu usaha.

\subsection{Brand (Merk)}

Brand (merk) merupakan atribut penting untuk produk, yangmana merk produk akan memunculkan nilai tambah produknya. Merk bukan saja memunculkan kesan tetapi juga harus menempatkan pada posisi khusus pada pikiran seseorang . Apabila merk tidak mendapat respon dibenak konsumen, maka ada kesempatan untuk pesaing menggantikan posisi tersebut, karenanya dibutuhkan merk yang paten. Cara termudah membedakan antar merk yakni dilihat dari serangkaian kesatuan dengan dibandingkannya kekhususan relatifnya.

Kotler dan Gary Armstrong (2004) menyatakan merk yaitu sebuah nama, istilah, tanda, simbol, rancangan, atau kombinasi dengan tujuan guna mengenali produk atau jasa produsen serta agar dapat dibedakan atas produk lain. Disampaikannya suatu kesimpulan, sifat, manfaat, dan jasa spesifik secara konsisten kepada pembelilah yang merupakan janji dari produsen atas adanya merk yang mereka miliki. Merk dapat menyampaikan empat tingkat arti: (1) Atribut. (2) Manfaat. (3) Nilai. dan (4) Kepribadian.

\section{METODE PENELITIAN}

\subsection{Persiapan}

Tim PKM melakukan persiapan awal sebelum dilakukannya pelaksanaan pengabdiaan kepada masyarakat yakni berupa survei lokasi dan identifikasi masalah di pelaku usaha 
UMKM telur asin, agar diketahui apa yang dibutuhkan oleh pelaku usaha UMKM telur asin di Kelurahan Genuksari Kecamatan Genuk.

\subsection{Pelaksanaan}

Kegiatan berikutnya adalah dilakukannya pelatihan dan penyuluhan terkait manajemen usaha dan merk, yangmana pelatihan dikiuti oleh pelaku usaha UMKM telur asin di Kelurahan Genuksari Kecamatan Genuk. Saat melaksanakan PKM ini Tim PKM berbagi tugas sesuai dengan bidang keahlian ilmu masing-masing dalam memberikan pelatihan dan penyuluhan.

\subsection{Monitoring}

Dengan selesainya pelatihan dan penyuluhan kepada pelaku usaha UMKM telur asin maka Tim PKM selanjutnya melakukan monitoring dengan tujuan untuk mengetahui apakah usaha yang dijalankan pasca pelatihan dan penyuluhan telah dilaksanakan sesuai dengan ilmu yang telah mereka terima di pelatihan dan penyuluhan yang sudah mereka ikuti. Apabila ternyata belum sesuai dengan ilmu yang telah mereka terima di pelatihan dan penyuluhan yang sudah mereka ikuti maka mengapa dan kendala apa saja yang mereka hadapimya, sehingga Tim PKM bisa mencarikan solusinya.

\section{HASIL DAN PEMBAHASAN}

Tahap-tahap dalam pelaksanaan kegiatan pengabdian sebagai berikut:

1) Melakukan survei lokasi yang menjadi obyek PKM yaitu pada pelaku usaha UMKM telur asin di Kelurahan Genuksari Kecamatan Genuk Semarang dan melakukan wawancara awal secara mendalam (indepth interview) dengan Kepala Kelurahan Genuksari tentang rencana pelaksanaan kegiatan PKM.

2) Kepala Kelurahan Genuksari menentukan waktu, tempat dan calon peserta untuk kegiatan pengabdian kepada masyarakat dan kemudian membagikan undangan kepada pelaku usaha UMKM telur asin untuk hadir mengikutinya.

3) Tim PKM melaksanakan pengabdian kepada masyarakat selama 1 hari yaitu pada: Minggu, 28 Juli 2019 yang diikuti sebanyak 37 orang dan bertempat di Aula kantor Kelurahan Genuksari.

Pelaksanaan kegiatan PKM ini menggunakan metode ceramah, diskusi, tanya jawab secara langsung dan contoh kasus. Peserta pelaku usaha UMKM telur asin mendapat masukan dari pemateri tentang bagaimana me-manage suatu usaha khususnya telur asinnya dan membuat merk untuk usaha telur asinnya. Kegiatan PKM inipun mendapatkan sambutan yang baik dari para pelaku usaha UMKM telur asin. Hal ini terlihat dari keseriusan mereka untuk ikut terlibat secara langsung dalam diskusi dan dalam menangani contoh kasus manajemen usaha dan merk. 
Tabel 1. Pelaksanaan PKM

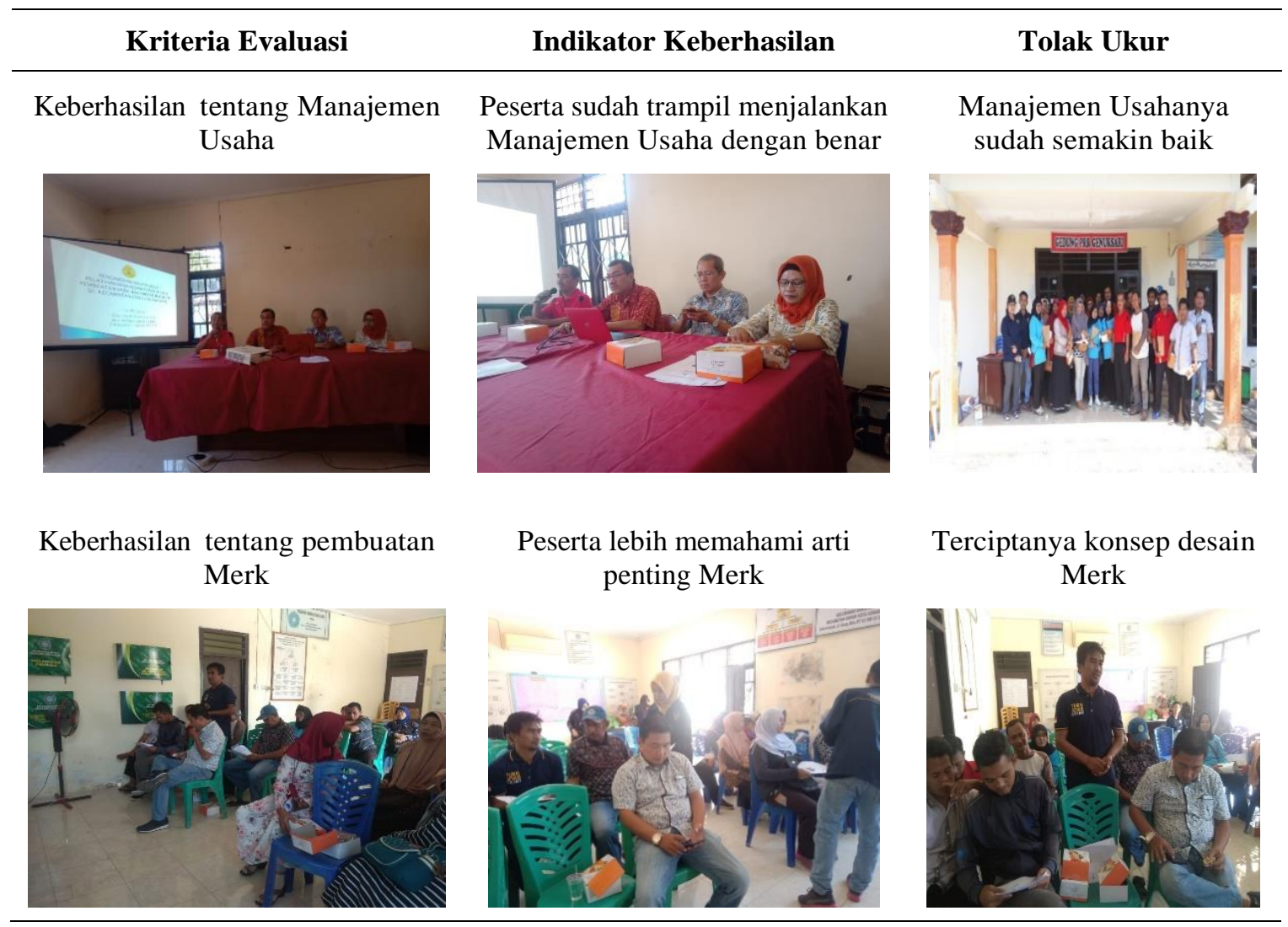

Dari hasil kegiatan PKM tentang manajemn usaha dan pembuatn merk kepada pelaku usaha UMKM telur asin di Kecamatan Genuk, maka dapat disimpulkan sebagai berikut: (1) Meningkatnya pemahaman dan pengetahuan tentang tentang Merk dan Manajemen Usaha pada pelaku usaha UMKM telur asin di Kelurahan Genuksari Kecamatan Genuk. (2) Meningkatnya ketrampilan pada pelaku usaha UMKM telur asin di Kelurahan Genuksari Kecamatan Genuk tentang Merk dan Manajemen Usaha dalam memahami kasus manajemen usaha dan merk.

\section{DAFTAR PUSTAKA}

Amirullah. (2015). Pengantar Manajemen. Jakarta: MitraWacana Media.

Ardana, Komang, Ni Wayan Mujiati, dan I Wayan Mudiartha Utama. (2012). Manajemen Sumber Daya Manusia. Yogyakarta. Graha Ilmu

Choliq, Abdul. (2011). Pengantar Manajemen, Semarang. Rafi Sarana Perkasa

Hasibuan, Malaayu, S.P, (2011). Manajemen: Dasar, Pengertian, dan Masalah. Edisi Revisi. Jakarta. Bumi Aksara

Kotler, Philip. (2010). Manajemen Pemasaran (Analisis, Perencanaan, dan Pengendalian), Terjemahan Jaka Wasana, Institut dan Pembinaan Manajemen, Jilid I, Edisi Kelima, Cetakan Ketujuh. Jakarta. Erlangga 
JATTEC, Vol. 1, No. 1, Januari 2020: 14-20

Kotler, Philip dan Gary Amstrong. (2008). Prinsip-prinsip Pemasaran. Jilid 1. Jakarta. Erlangga

Undang-undang Nomor 20 tahun 2008 tentang Usaha Mikro, Kecil dan Menengah 